\title{
"Isolation and Biochemical Characterization of Antibiotic Producing Microorganism from Waste Soil Samples of Certain Industrial areas of India"
}

\author{
Atul Pratap Singh and Sanjay Mishra \\ School of Biotechnology, IFTM University, Lodhipur Rajput, Delhi Road (NH-24), Moradabad 244102, U.P.,
} India.

\begin{abstract}
The search for new antibiotics continues in a rather overlooked hunting ground. In the course of screening for new antibiotic-producing microorganisms, isolates showing antimicrobial activity were isolated from waste soil samples from various habitats in the Industrial Areas in Dheradun, Uttarakhand, India. Existing methods of screening for antibiotic producers together with some novel procedures were reviewed. Both modified agar-streak and agar-plug methods were used in the primary screens. The use of selective isolation media, with or without antibiotic incorporation and/or heat pretreatment, enhanced the development of certain actinomycete colonies on the isolation plates. Antibiotics have long been considered the "magic bullet" that would end infectious disease. Although they have improved the health of countless numbers of humans and animals, many antibiotics have also been losing their effectiveness since the beginning of the antibiotic era. Bacteria have adapted defenses against these antibiotics and continue to develop new resistances, even as we develop new antibiotics. In recent years, much attention has been given to the increase in antibiotic resistance. As more microbial species and strains become resistant, many diseases have become difficult to treat, a phenomenon frequently ascribed to both indiscriminate and inappropriate use of antibiotics in human medicine. However, the use of antibiotics and antimicrobials in raising food animals has also contributed significantly to the pool of antibiotic resistant organisms globally and antibiotic resistant bacteria are now found in large numbers in virtually every ecosystem on earth. Dual culture bioassays were used to screen seven selected Bacillus isolates for activity against four plant pathogenic fungi in vitro. All isolates were able to inhibit the pathogens to varying degrees. Two isolates, R29 and B81, were selected for further testing and characterization. Further bioassays were performed on five complex nutrient media which were adjusted to $\mathrm{pH}$ S.S and 7, and both incubated at $2 \mathrm{SoC}$ and $30^{\circ} \mathrm{C}^{\prime \prime}$ respectively. It was found that $\mathrm{pH}$ and media composition showed significant influences on the antifungal activities of the isolates tested, but that a SoC temperature difference in incubation temperature did not. Tryptone soy agar was found to give rise to the largest inhibition zones. Both isolates were tentatively identified using standard biochemical and morphological tests. Based on its phenotypic characteristics, $R 29$ was identified as a strain of B. subtilis. B81 proved to be more difficult to assign to a specific group or species of Bacillus, though B. subtilis and B. licheniformis were considered to be the nearest candidates. Genomic DNA was extracted from both isolates and a portion of each of their 16s rDNA genes were amplified and sequenced for homology testing against the GeneBank database. Homology testing confirmed that both isolates were members of the genus Bacillus and most probably strains of B. subtilis. The DNA fragment used for sequencing proved to be too small to give conclusive identification of the isolates.
\end{abstract}

Key Words: Collection of soil samples, Isolation techniques for bacterial and fungal spp by different microbiological methods, Dilutions, Biochemical characterization.

\section{Introduction}

In the beginning of 20th century, the idea of growth inhibition of one microorganism present in the vicinity of other one came into existence. Later, it was demonstrated that growth inhibition of the former microorganism was mediated by secretion of toxic metabolites by the later. This toxic metabolite was termed as 'antibiotic' and the phenomenon of act of growth inhibition by antibiotics as 'antibiosis. The antibiotics are defined as "the complex chemical substances, the secondary metabolites which are produced by microorganisms and act against other microorganisms". In nature, there is universal distribution of antibiosis among the microorganisms owing to which they are involved in antagonism. Those microorganisms which have capacity to produce more antibiotics can survive for longer time than the others producing antibiotics in less amount. However, antibiotics produced by microorganisms have been very useful for the cure of certain human diseases caused by bacteria, fungi and protozoa. Due to continuous endeavor made in this field, the antibiotics discovered at present are about 5,500. Total world production of antibiotics is more than one million tons per annum. This success has been possible only due to continuous researches made during the last 4 decades. 
The diversity of soil microorganisms were of great significance as a factor promoting the early discovery of antibiotics [1]. Many types of microorganisms such as moulds, bacteria, protozoa and algae, all competing for limited nutrients in the soil, have to devise strategies to survive. Among these microbes are autotrophs, free living nitrogen fixers, thermopiles, acidophiles, pathogens and saprophytes [1]. Natural product antimicrobials have been used for centuries by native peoples all around the world, but it wasn't until the late 1800 s that people began to search for single compounds that could be used to kill disease causing bacteria. Soil and plants had been used to prevent wounds from becoming infected or to treat rashes as far back as the Roman and Byzantine empires. All cultural groups have medicinal folklore that has some level of effectiveness for any number of ailments. Many modern common therapeutic agents have their origins in natural sources, such as: Paclitaxel, also known as Taxol, which was derived from the yew tree Morphine, is derived from the opium poppy; Atropine comes from the belladonna leaf; and Aspirin is from white willow bark [1].

The actinomycetes yielded about $70 \%$ of these, and the remaining $30 \%$ are products of filamentous fungi and non-actinomycete bacteria [2-5]. Most of the bioactive compounds from actinomycete sort into several major structural classes such as amino glycosides (e.g., streptomycin and kanamycin), ansamycins (e.g., rifampin), anthracyclines (e.g., doxorubicin), b-lactam (cephalosporins), macrolides (e.g., erythromycin), and tetracycline. The objectives of this experiment were to survey for antibiotic-producing bacteria found in soil and isolate and characterize antibiotics produced by soil-borne bacteria. Putative antibiotic-producing bacteria were isolated from soil and antibiotic production was confirmed. It was hypothesized that antibiotic-producing bacteria would be of the genera Bacillus or Streptomyces and that the antibiotics would be peptides that inhibited the growth of Gram-positive bacteria [6-9]. The first truly effective class of antimicrobial drugs was the sulfonamides, discovered by Gerhard Domagk. In 1932, two scientists at the Bayer Company, Mietzsch and Klarer, synthesized Prontosil red, a red dye bound to a sulfonamide group. Domagk showed, in 1935, that infections in mice caused by hemolytic streptococci were cured by Prontosil red [10, 11]. Unfortunately for Bayer, Prontosil red was shown to have no antibacterial activity in vitro. This lack of activity was explained by several researchers [12-18] showing that Prontosil red is split in vivo into its component dye and sulfanilamide, the active antibacterial agent and a previously described molecule that was already in the public domain. From that point, sulfanilamide was manufactured by a number of companies and work was begun to modify the molecule to enhance performance, leading to decreased side effects and a broader spectrum of action.

\section{1: Collections of soil samples from different places:}

\section{Materials And Methods}

The soil samples were collected from in an around Dheradun, Industrial Areas Uttarakhand, India. The soil samples were dried separately at $37^{\circ} \mathrm{C}$ for 1 hour in hot air oven. Then they were cooled at room temperature. $1 \mathrm{gm}$ of each soil sample was added to a conical flask containing $100 \mathrm{ml}$ of sterile water and few drops of Tween-80 solution. All flasks were shaken for 30 minutes in orbital shaker incubator at $27^{\circ} \mathrm{C}$. These flasks were considered as stock cultures.

\section{2: Isolation of Microbes:}

The sample is mixed with $1 \mathrm{~L}$ pure water to make solution sample. This solution sample is diluted up to 10-5 serial dilution. Serial dilution is a process of diluting a sample several times. The sterile Petri dish is label. Than $90 \mathrm{ml}$ of phosphate buffer is transferred into each of 5 tubes using sterile pipettes (10ml) with aseptic technique. By using sterile pipette $(1 \mathrm{ml}), 1 \mathrm{ml}$ of water sample is transferred into 10-1 tube. Mix the test tube properly. Continue dilution with aseptic technique for test 10-2 until 10-5. After that each of serial dilution is transferred into nutrient agar plate by using spread plate method. $0.1 \mathrm{ml}$ of an appropriately diluted culture is spread over the surface of agar using sterile glass spreader. The plate is then incubated until the colonies appear. It is important that the surface of the plate be fairly dry so that the spread liquid soaks in.

\section{3: Preliminary screening of crude antibiotic produced}

Agar Streak Method: The microbial sensitivity of the soil isolates were analyzed by Agar streak method'. Each of the isolate was streaked as a straight line on SBCD medium and incubated at $27^{\circ} \mathrm{C}$ for about 6 days After 6 days, different strains of microorganisms were streaked at right angle, but not touching to the streak and incubated at $37^{\circ} \mathrm{Cfor} 24$ hours in case of bacteria and $27^{\circ} \mathrm{Cfor} 48$ hours in case of fungi. If, the organism is sensitive against the antibiotic produced by actinomycetes, then it will not grow near the actinomyces [Table 1].. Test of Microorganisms: The test bacteria that were used in this study include references, environmental as well as clinical isolates. The typical reference strains were as follows:

Gram Positive Bacteria: Staphylococcus aureus, Streptococcus faecalis, Streptococcus pyogens, Bacillus cereus, Acinetobacter calcaoceuticus.

Gram Negative Bacteria: Escherichia coli, Pseudomonas aeruginosa, Proteus vulgaris, Klebsiella pneumonia, Bacillus subtilis. 
Table 1:

Morphological and Cultural

Characterization:

\begin{tabular}{|c|c|c|}
\hline Results (slant/butt) & Symbol & Interpretation \\
\hline Red/yellow & $\begin{array}{l}\text { Alkaline reaction/ Acid } \\
\text { production }\end{array}$ & $\begin{array}{l}\text { Glucose fermentation only; } \\
\text { Peptone catabolized }\end{array}$ \\
\hline Yellow/yellow & $\begin{array}{l}\text { Acid production / Acid } \\
\text { production }\end{array}$ & $\begin{array}{l}\text { Glucose and lactose and/or } \\
\text { sucrose fermentation }\end{array}$ \\
\hline Red/red & $\begin{array}{l}\text { Alkaline reaction / } \\
\text { Alkaline reaction }\end{array}$ & $\begin{array}{l}\text { No fermentation; Peptone } \\
\text { catabolized }\end{array}$ \\
\hline Red/no color change & $\begin{array}{l}\text { Alkaline reaction / No } \\
\text { Change }\end{array}$ & $\begin{array}{l}\text { No fermentation; Peptone used } \\
\text { aerobically }\end{array}$ \\
\hline $\begin{array}{l}\text { Yellow/yellow with } \\
\text { bubbles }\end{array}$ & $\begin{array}{l}\text { Acid production / Acid } \\
\text { production, Gas } \\
\text { production }\end{array}$ & $\begin{array}{l}\text { Glucose and lactose and/or } \\
\text { sucrose fermentation; Gas } \\
\text { produced }\end{array}$ \\
\hline Red/yellow with bubbles & $\begin{array}{l}\text { Alkaline reaction / Acid } \\
\text { production, Gas } \\
\text { production }\end{array}$ & $\begin{array}{l}\text { Glucose fermentation only; } \\
\text { Gas produced }\end{array}$ \\
\hline $\begin{array}{l}\text { Red/yellow with bubbles } \\
\text { and black precipitate }\end{array}$ & $\begin{array}{l}\text { Alkaline reaction / Acid } \\
\text { production, Gas } \\
\text { production, H2S }\end{array}$ & $\begin{array}{l}\text { Glucose fermentation only; } \\
\text { Gas produced; H2S produced }\end{array}$ \\
\hline $\begin{array}{l}\text { Red/yellow with black } \\
\text { precipitate }\end{array}$ & $\begin{array}{l}\text { Alkaline reaction / } \\
\text { Alkaline reaction, } \mathrm{H} 2 \mathrm{~S}\end{array}$ & $\begin{array}{l}\text { Glucose fermentation only; } \\
\text { H2S produced }\end{array}$ \\
\hline $\begin{array}{l}\text { Yellow/yellow with } \\
\text { black precipitate }\end{array}$ & $\begin{array}{l}\text { Acid production / Acid } \\
\text { production, } \mathrm{H} 2 \mathrm{~S}\end{array}$ & $\begin{array}{l}\text { Glucose and lactose and/or } \\
\text { sucrose fermentation; H2S } \\
\text { produced }\end{array}$ \\
\hline No change/no change & No Change & No fermentation \\
\hline
\end{tabular}

\section{Morphological Characterization:}

Cultural Characterization: Morphological and cultural characters of the selected actinomycetes strains were studied by inoculating the selected strain into sterile International Streptomycetes Project (ISP) media like the media were sterilized and poured into sterile petridishes. After solidification of the media, culture of the selected strain was streaked on the media surface by simple method aseptically and incubated at $27^{\circ} \mathrm{C}$ for 7 days. Morphological characters such as colony characteristics, type of aerial hyphae, growth of vegetative hyphae, fragmentation pattern, spore formation and nature of fermentation were observed [Table 1].

* Tryptone - Yeast extract broth

* Oatmeal agar

* Inorganic salts - Starch Agar

* Glycerol - Aspargine Agar

* Peptone - Yeast extract agar

* Tyrosine Agar

* Carbon utilization agar

The media were sterilized and poured into sterile petridishes. After solidification of the media, culture of the selected strain was streaked on the media surface by simple method aseptically and incubated at $27^{\circ} \mathrm{C}$ for 7 days. Morphological characters such as colony characteristics, type of aerial hyphae, growth of vegetative hyphae, fragmentation pattern and spore formation were observed

\section{Results And Discussion:}

Isolation Results: The isolation process is a procedure of isolation the mixture of colonies to a single colony. This process was done by using streaking method to obtain pure cultures. The soil's sample was added with 1 Liter pure water to obtain solution sample before transferred into nutrient agar plate. It is important that the numbers of colonies developing on the plates are not being too large. On crowded plates some cells may not form colonies, and some colonies may fuse, leading to erroneous measurements. So, to obtain the appropriate colony number, the samples need to be diluted. This solution samples were diluted up to 10-5. By using spread plate method, the diluted samples were transferred into nutrient agar plate and the bacteria were grown on it. From the observation, these samples take about three until four days to growth on the plate. Table 2 (A \& B) and Figure 1 show the growth of the bacteria on plate after 5 days.

Collection of soil samples and number of microbial strains \& Actinomycetes in isolation plates: The projection of aerial mass is well explained in Table $2(A \& B)$ and illustrated in Figure 1. 
Table 2: (A): Number of Microbial Strains

\begin{tabular}{|c|c|c|c|c|c|c|c|c|}
\hline \multirow[t]{2}{*}{$\begin{array}{l}\text { Sr. } \\
\text { No. }\end{array}$} & \multirow{2}{*}{$\begin{array}{l}\text { Dilution of } \\
\text { soil samples } \\
\left(10^{-6}\right)\end{array}$} & \multirow{2}{*}{$\begin{array}{l}\text { Heat treatment } \\
\left(45^{\circ} \mathrm{C} \text { for } 1\right. \\
\text { hour })\end{array}$} & \multicolumn{4}{|c|}{$\begin{array}{l}\text { No. of Actinomycetes and bacterial strains } \\
\text { (colonies) on isolation media }\end{array}$} & \multirow{2}{*}{$\begin{array}{l}\text { Nature of soil } \\
\text { sample } \\
\text { (Surface \& sub } \\
\text { surface) }\end{array}$} & \multirow[t]{2}{*}{$\begin{array}{l}\mathrm{pH} \text { of } \\
\text { soil }\end{array}$} \\
\hline & & & SBCD & AIA & SCA & TSA & & \\
\hline 1 & $10^{-5}$ & NA & -- & -- & -- & -- & Dry soil sample & 7.4 \\
\hline 2 & $10^{-5}$ & NA & -- & -- & -- & -- & Water logged & 7.5 \\
\hline 3 & $10^{-4}$ & $\mathrm{AP}$ & 4 & 5 & -- & 10 & mud & 7.5 \\
\hline 4 & $10^{-4}$ & AP & 3 & 6 & -- & 14 & Water logged & 6.5 \\
\hline 5 & $10^{-3}$ & $\mathrm{AP}$ & -- & 5 & -- & 16 & mud & 7.0 \\
\hline 6 & $10^{-4}$ & AP & -- & -- & -- & 20 & Loam & 6.8 \\
\hline 7 & $10^{-5}$ & AP & -- & 13 & 15 & 25 & Sandy & 7.8 \\
\hline 8 & $10^{-6}$ & $\mathrm{AP}$ & 15 & 48 & 36 & 25 & Mud & 5.6 \\
\hline 9 & $10^{-6}$ & AP & 35 & 50 & 32 & 30 & $\begin{array}{l}\text { Black dry soil } \\
\text { sample } \\
\text { Black wet soil } \\
\text { sample } \\
\text { Red dry soil } \\
\text { sample }\end{array}$ & 5.7 \\
\hline
\end{tabular}

NA: Not applied, AP: Applied SBCD - Soyabean casein digest medium, TSA: Tryiptase soya agar, AIA Actinomycetes isolation agar, SCA - Starch casein agar.

Table 2: (B): Aerial Mass Distinction of Actinomyces

\begin{tabular}{|c|c|c|}
\hline Sl.no & Strains & Aerial mass of colour \\
\hline 1 & B2 & W (White colour) \\
\hline 2 & BS & (Gray colour) \\
\hline 3 & $\mathrm{CO}$ & Gy \\
\hline 4 & CS & Gy \\
\hline 5 & $\mathrm{C} 1$ & WGy (White gray colour) \\
\hline 6 & C 8 & Gy \\
\hline 7 & C9 & (W) Gy \\
\hline 8 & C11 & $\mathrm{W}$ \\
\hline 9 & $\mathrm{C} 12$ & GyW \\
\hline 10 & D1 & $\mathrm{Y}$ \\
\hline 11 & MB1 & $\mathrm{W}$ \\
\hline 12 & MB2 & Gy \\
\hline 13 & MB3 & WGy \\
\hline 14 & MB5 & $\mathrm{W}(\mathrm{Gy})$ \\
\hline 15 & MB9 & $\mathrm{W}$ \\
\hline
\end{tabular}


Figure 1: Systematic Picture of Growth of Bacteria on Agar Plate with Specified Culture Time of 5 Days.

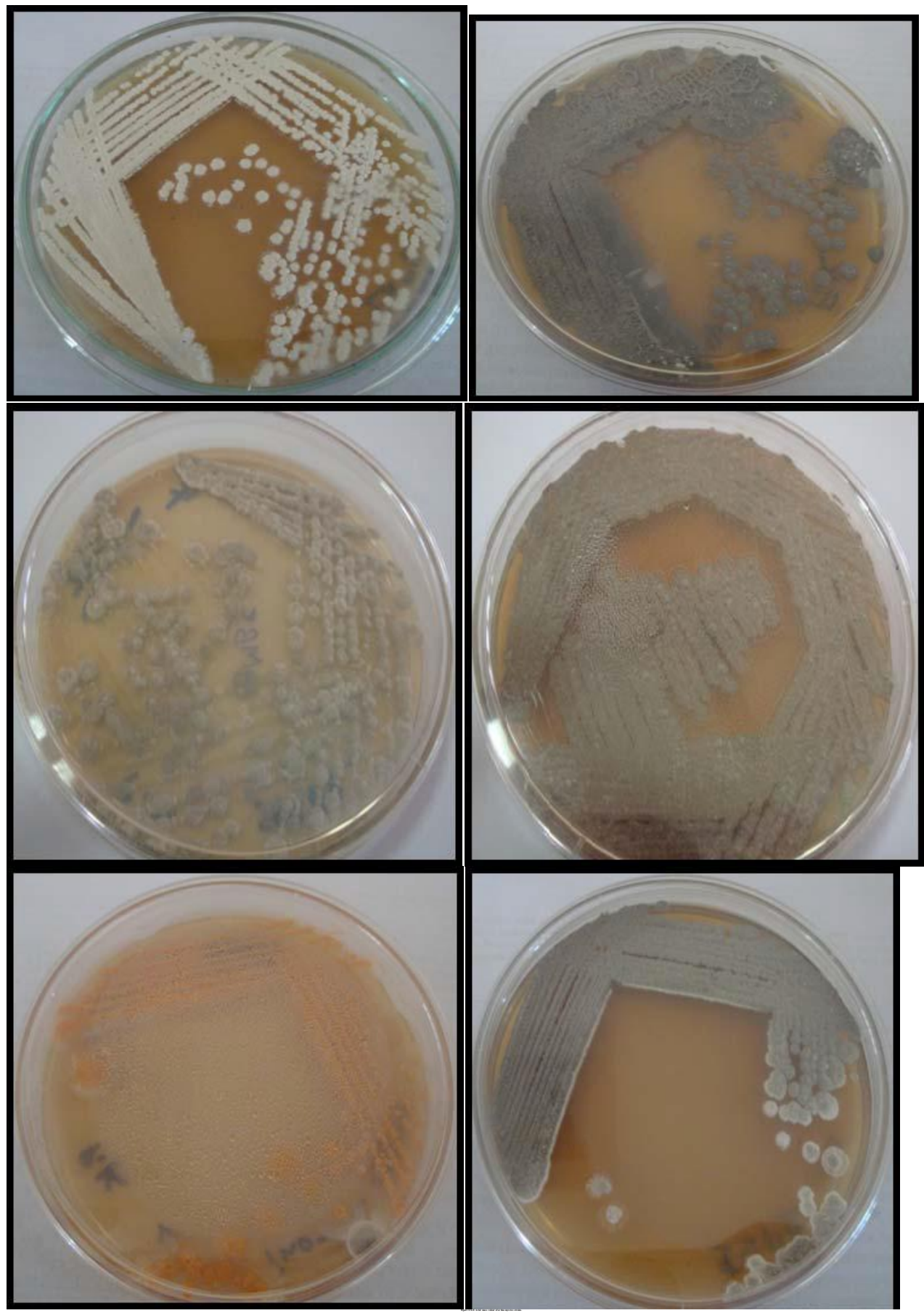




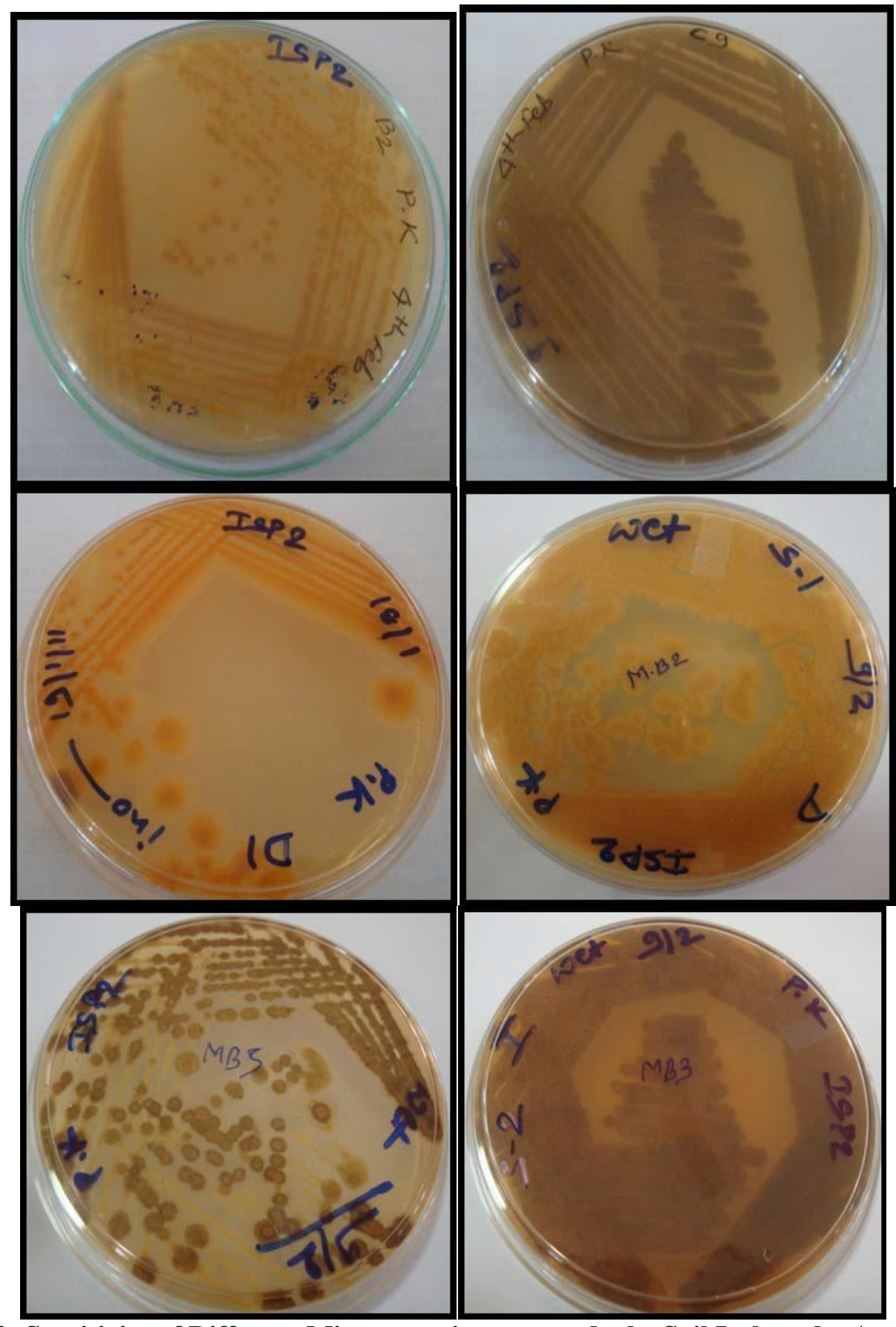

Figure 2: Sensitivity of Different Microorganisms towards the Soil Isolates by Agar Streak Method. 
Table 3: (A): Growth Inhibition Status Various Microorganisms by Soil Isolates

\begin{tabular}{|c|c|c|c|c|c|c|c|c|}
\hline $\begin{array}{l}\text { Soil } \\
\text { isolates }\end{array}$ & B.subtilis & S.aureus & E.coli & K.pneumoniae & P.aeruginosa & A.niger & A.terreus & C.albicans \\
\hline $\mathrm{A} 1$ & ++ & + & + & - & ++ & - & - & + \\
\hline A2 & + & ++ & + & - & ++ & _ & - & + \\
\hline A3 & - & - & ++ & - & ++ & _ & + & ++ \\
\hline A4 & ++ & ++ & +++ & ++ & + & + & - & ++ \\
\hline A5 & + & - & + & + & + & - & - & - \\
\hline A6 & + & - & + & - & - & - & - & - \\
\hline A7 & ++ & - & + & + & + & + & - & + \\
\hline A8 & _- & + & + & + & _ & + & + & _- \\
\hline A9 & & + & & + & & & & \\
\hline
\end{tabular}

$+++=$ Better inhibition, $++=$ Good inhibition, $+=$ Moderate inhibition, $-=$ No inhibition

Table 3 (B): : Taxonomical Characterization of Soil Isolates

\begin{tabular}{|c|c|c|c|c|c|c|c|c|}
\hline $\begin{array}{c}\text { Soil } \\
\text { isolates }\end{array}$ & $\begin{array}{l}\text { Melanoid } \\
\text { formation }\end{array}$ & $\begin{array}{l}\text { Nitrate } \\
\text { reduction }\end{array}$ & $\begin{array}{l}\text { Proteolytic } \\
\text { activity }\end{array}$ & $\begin{array}{l}\text { Gelatin } \\
\text { liquefication }\end{array}$ & $\begin{array}{l}\text { Starch } \\
\text { hydrolysis }\end{array}$ & $\begin{array}{l}\text { Carbon } \\
\text { assimilation }\end{array}$ & $\begin{array}{l}\text { Acid } \\
\text { production }\end{array}$ & $\begin{array}{l}\mathrm{H}_{2} \mathrm{~S} \\
\text { production }\end{array}$ \\
\hline A-1 & $\begin{array}{l}\text { Light brown } \\
\text { pigmentation }\end{array}$ & + & $\begin{array}{l}\text { Clear with } \\
\text { acidic } \\
\text { reaction }\end{array}$ & + & + & Glucose & + & - \\
\hline A-2 & Only growth & + & $\begin{array}{l}\text { Clear with } \\
\text { acidic } \\
\text { reaction }\end{array}$ & + & + & Glucose & + & - \\
\hline A-3 & Only growth & + & $\begin{array}{l}\text { Not clear } \\
\text { with } \\
\text { slightly } \\
\text { alkaline } \\
\text { reaction }\end{array}$ & + & + & Fructose & + & + \\
\hline A-4 & $\begin{array}{l}\text { Light brown } \\
\text { pigmentation }\end{array}$ & + & $\begin{array}{l}\text { Not clear } \\
\text { with } \\
\text { acidic } \\
\text { reaction }\end{array}$ & + & + & Lactose & + & + \\
\hline A-5 & Only growth & + & - & + & + & Lactose & + & - \\
\hline A-6 & $\begin{array}{l}\text { Light brown } \\
\text { pigmentation }\end{array}$ & + & - & + & + & Maltose & + & - \\
\hline
\end{tabular}

Table 4: Morphological and Cultural Characterization of the Microbial Strain.

\begin{tabular}{|l|l|l|}
\hline $\begin{array}{l}\text { Serial } \\
\text { No. }\end{array}$ & $\begin{array}{l}\text { Medium used for the } \\
\text { growth of } \\
\text { microorganisms }\end{array}$ & A-4 Microbial strains \\
\hline 1 & $\begin{array}{l}\text { Tryptone-yeast extract } \\
\text { broth } \\
\text { (TSP-1) }\end{array}$ & Growth occurs by the pellicle formation. \\
\hline 2 & ISP-2 & $\begin{array}{l}\text { Creamish white colored colonies with clear zone } \\
\text { around it were observed. }\end{array}$ \\
\hline 3 & (Oatmeal agar) ISP-3 & $\begin{array}{l}\text { Slight black - creamish color thick colonies; no aerial } \\
\text { mycelium formation was observed. }\end{array}$ \\
\hline
\end{tabular}




\begin{tabular}{|l|l|l|}
\hline 4 & $\begin{array}{l}\text { Inorganic salt-starch agar } \\
\text { (ISP-4) }\end{array}$ & $\begin{array}{l}\text { Blackish-brown colored thick colonies with waxy } \\
\text { margin and convex surface was observed. }\end{array}$ \\
\hline 5 & $\begin{array}{l}\text { Glycerol asparagines agar } \\
\text { base (ISP-5) }\end{array}$ & $\begin{array}{l}\text { Whitish colored thin colonies striated surface; with } \\
\text { less aerial mycelium and filamentous growth was } \\
\text { observed. }\end{array}$ \\
\hline 6 & $\begin{array}{l}\text { Peptone yeast extract iron } \\
\text { agar (ISP-6) }\end{array}$ & $\begin{array}{l}\text { Thin transparent colonies with black colored soluble } \\
\text { pigments were seen. No filamentous growth was } \\
\text { seen. }\end{array}$ \\
\hline 7 & $\begin{array}{l}\text { Tyrosine agar base (ISP- } \\
7)\end{array}$ & $\begin{array}{l}\text { Cream colored, lobe shape, convex surface, little } \\
\text { mycelium growth was observed. }\end{array}$ \\
\hline 8 & $\begin{array}{l}\text { Carbon utilization agar } \\
\text { (ISP-9) }\end{array}$ & $\begin{array}{l}\text { Thin yellowish golden colored colonies with little } \\
\text { mycelium growth were observed. }\end{array}$ \\
\hline
\end{tabular}

\section{Screening for antimicrobial activity:}

This study was done by the Cross streak method against five pathogenic strains of bacteria namely Pseudomonas, E.coli, Klebsiella, Bacillus and Proteus results shown in Table (4 \& 5) and

Figure 3.

Table 5: Screening for Antimicrobial Activity

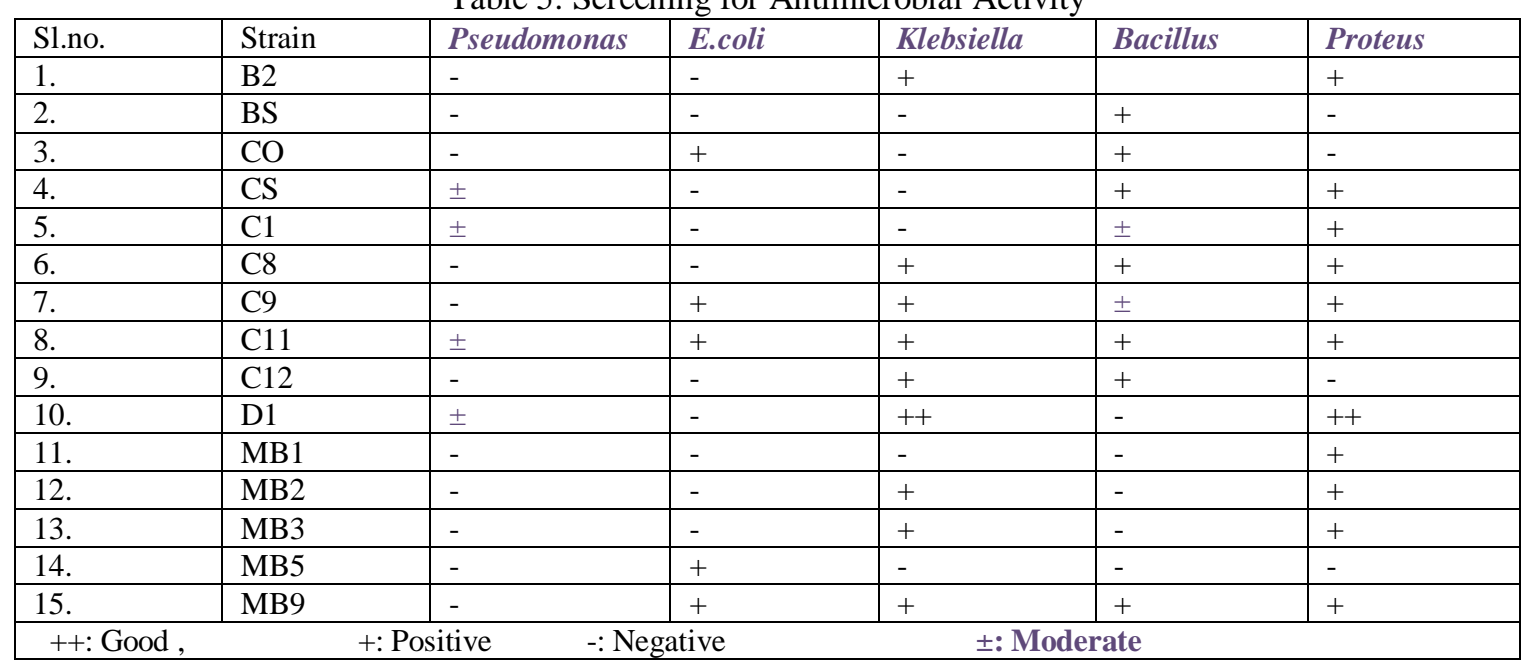

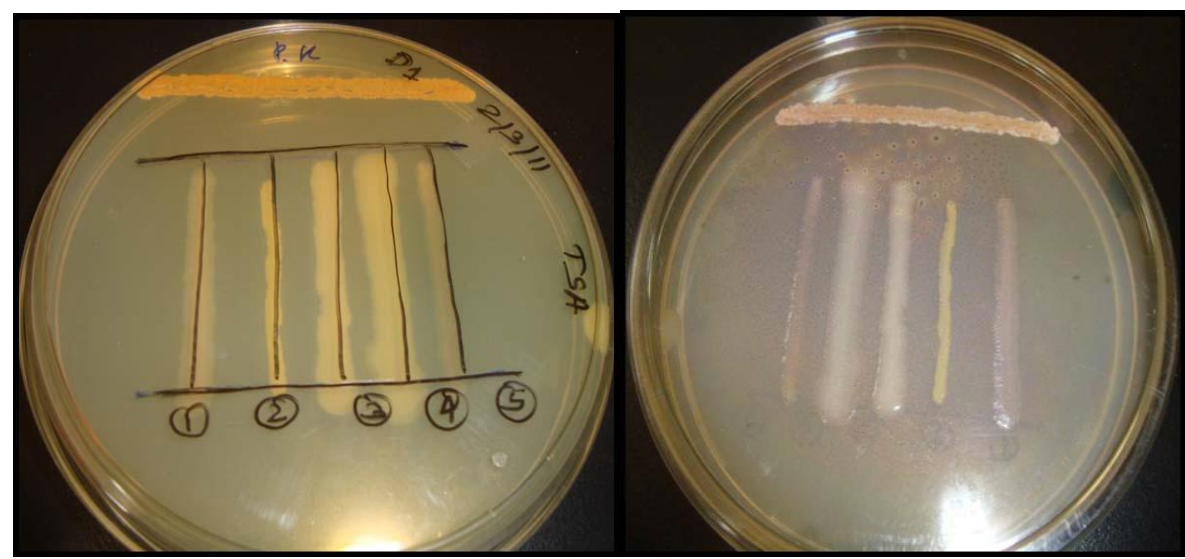

Figure 3: Screening of Antimicrobial Activity by Cross Streak Method Against Five Bacterial Pathogenic Strains.

Among all the strains only D1 has shown good antimicrobial activity against Klebsiella and Proteus. Growth of Proteus was inhibited by most of the strains. MB1 has shown activity against Proteus only. Pseudomonas was the least inhibited pathogenic strain CS, C11, C1 and D1 has shown moderate inhibition against it. E.coli has also shown very least resistance against any strains (Figure 4, A-I).. 


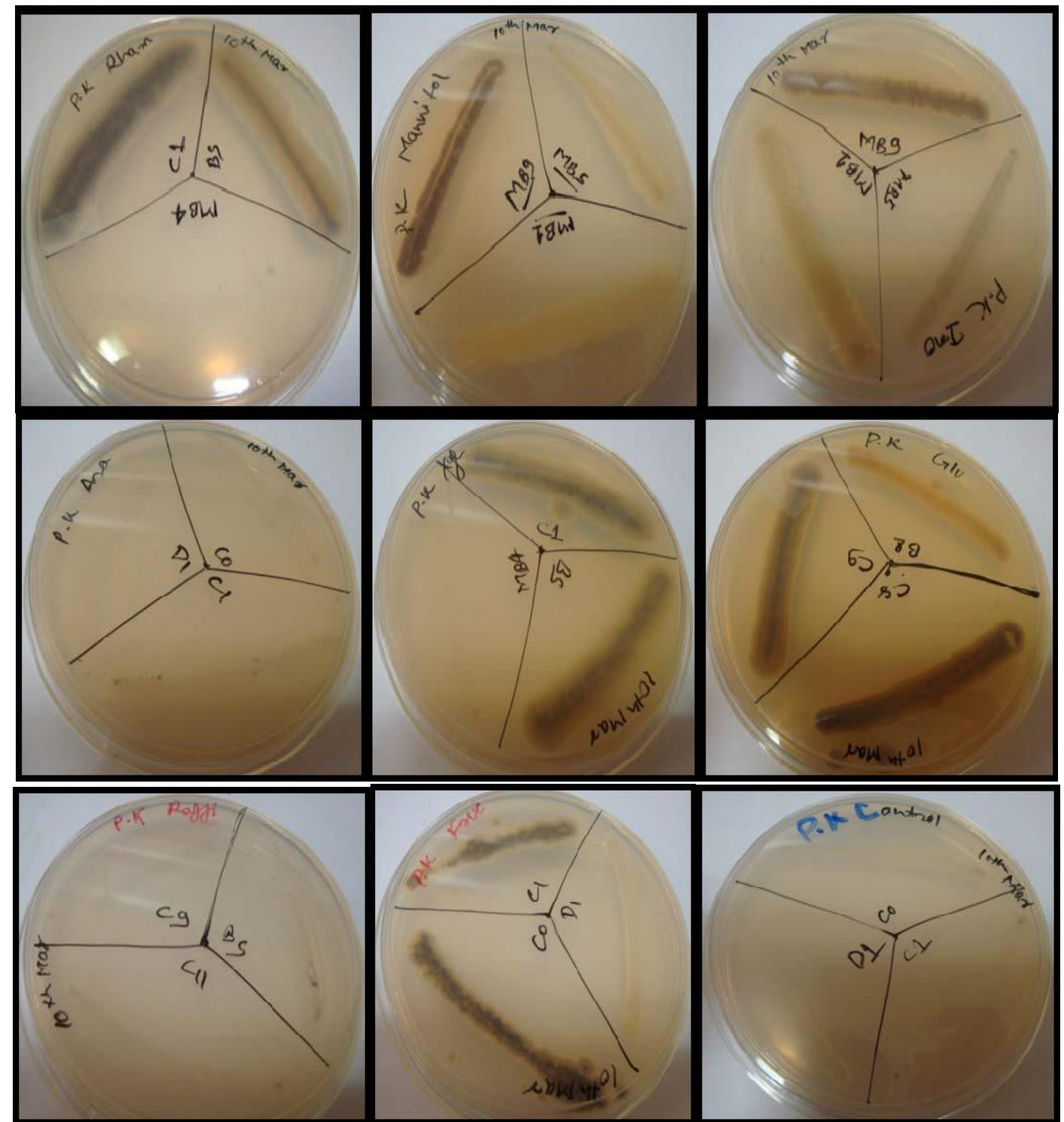

Figure 4 (A to I): Assimilation of Different Carbon Sources

\section{Concluding Remarks}

Soil sediment samples collected from the Dehradun pharmaceutical companies were divided in to two parts as wet sample and dry sample. Serial dilution of wet and dry was done the no of isolates from the dry sample was more in number. Marine sediment samples are good for the isolation of actinomycetes; Goodfellow and Hynes [12] reviewed the literature on isolation of actinomycetes from waste soil sediments and suggested that the waste soil sediment may be valuable for the isolation of novel actinomycetes. 15 isolates of actinomycetes was isolated from the samples. The characterization was done by the phenotypic characterization and species affiliation by physiological and biochemical characteristics described by Das et al. [9].

The aerial mass colour of almost all strains were Whitish grey and only one strain D1 has shown yellow colour. Recent reports $[17,18]$ further entail that white colour series of actinomycetes they were the dominant forms. Colour series were also recorded in soil, morphological observation of colonial characteristics such as amount and colour of vegetative growth, and the presence and colour of aerial mycelium and spores, and again the presence of diffusible pigments are recorded for each strain studied colonial growth on agar plate [19-25]. Concluding substantial activities are concerning with cellulose, caseinase, amylase, lipase and gelitinase with certain specific variations. 


\section{References}

[1]. Arifuzzaman.M, Khatun.M.R and Rahman.H, (2011), Isolation and screening of actinomycetes from Sundarbans soil for antibacterial activity, African Journal of Biotechnology Vol. 9(29), pp. 4615-4619.

[2]. Arora.A, Nain and J.K. Gupta, (2010), Solid-state fermentation of wood residues by Streptomyces griseus B1, a soil isolate, and solubilization of lignins World Journal of Microbiology \& Biotechnology (2005) 21: 303-308.

[3]. Arunachalam.R, Wesely.E.G, George.J and Annadurai, (2010). Novel Approaches for Identification of Streptomyces noboritoensis TBG-V20 with Cellulase Production, Current Research in Bacteriology 3 (1): 15-26.

[4]. Baskaran, R, Vijayakumar, R and Mohan, P. M,(2011) Enrichment method for the isolation of bioactive actinomycetes from mangrove sediments of Andaman Islands, India Malaysian Journal of Microbiology, Vol 7(1), 1-7.

[5]. Bentley SD, Chater KF, Cerdeno-Tarraga AM, Challis GL, Thompson NR, James KD, Harris DE, Quail MA, Kieser H, Harper D,(2011), Complete genome sequence of the model actinomycete Streptomyces coelicolor A3(2) Nature. $417: 141$ 147.

[6]. Berg, G., P. Marten and G. Ballin, (2010). Stenotrophomonas maltophilia in the rhizosphere of oilseed rape: Occurrence, characterization and interaction with phytopathogenic fungi. Microbiol. Res., 151: 19-27.

[7]. Boettger, E.C. (2009), Rapid determination of bacterial ribosomal RNA Sequences by direct sequencing of enzymatically amplified DNA. FEMS Microbiology Letters 65, 171-174.

[8]. Bredholt, H., Fjaervik, E., Jhonsen, G. and Zotechev, S. B. (2010). Actinomycetes from sediments in the Trondhein Fjrod, Norway: Diversity and biological activity. Journal of Marine Drugs 6, 12-24.

[9]. Das,S, Lyla,P.S and Khan,S.A,(2009), Distribution and generic composition of culturable marine actinomycetes from the sediments of Indian continental slope of Bay of Bengal Chinese Journal of Oceanology and Limnology Vol. 26 No. 2, 166-177.

[10]. Dhanasekaran, D, Selvamani,S , Panneerselvam.A and Thajuddin.N, (2009), Isolation and characterization of actinomycetes in Vellar Estuary, Annagkoil, Tamil Nadu African Journal of Biotechnology Vol. 8 (17), 4159-4162.

[11]. Don L. Crawford,t,James M. Lynch, John,M. Whipps, And Margaret, A. OUSLEY(2009), Isolation and Characterization of Actinomycete Antagonists of a Fungal Root Pathogen Applied and environmental Microbiology, 3899-3905.

[12]. Goodfellow, M and Haynes, (1984), Actinomycetes in marine sediments in Biological, biochemical and biomedical aspects of actinem(eds.) Ortiz-ortiz, I.,L.F. Bjalil and V.Yakoleff, Academic Press, London.453-472.

[13]. Gurung.T.D, Sherpa.C, Agrawal. P.V and Lekhak.B, (2010), Isolation and Characterization of Antibacterial Actinomycetes from Soil Samples of Kalapatthar, 173182.

[14]. Hong.K, Gao.A.H, Xie.Q,Y, Gao.H, Zhuang.L, Lin.H.P, Yu.H.P, LI.J, Yao.X.S, (2010), Actinomycetes for Marine Drug Discovery Isolated from Mangrove Soils and Plants in China, licensee Molecular Diversity Preservation International, Basel, Switzerland, 7(1): 24-44.

[15]. Jeffrey, L.S.H, Sahilah, A.M, Son R, Tosiah S (2011). Isolation and screening of actinomycetes from Malaysian soil for their enzymatic and antimicrobial activities, Journal of Tropical Agriculture and Food Sciences. 35: 159-164.

[16]. Jensen, P. R., Gontang, E., Mafnas, C., Mincer, T. J. and Fenical, W. (2005).Culturable marine Actinomycetes diversity from tropical Pacific Ocean sediments. Applied and Environmental Microbiology 7, 1039-1048.

[17]. Kumar,S.V, Sahu, M.K and Kathiresan .K (2005), Isolation and characterization of streptomycetes producing antibiotics from a mangrove environment, Asian Jr. of Microbial. Biotech Env. Sc.Vol. 7 No. (3); 457-464.

[18]. Kumar.K.S, Haritha.R, Mohan.Y.S.Y.V and Ramana.T, (2011), Screening of marine Actinobacteria for Antimicrobial Compounds, Research Journal of Microbiology 6(4): 385-393.

[19]. Lakshmipathy.D and Kannabiran.K, (2010), Isolation and Characterization of Antagonistic Actinomycetes from Marine Soil, Journal of Microbial \& Biochemical Technology, 2(1) : 001-006.

[20]. Lechevalier. M.P. and. Lechevalier.H.A, (2008). Procedures for studying and characterizing actinomycetes with emphasis on streptomycetes. Part III. A university laboratory approach (emphasis on generic characterization). In: Actinomycete Taxonomy (Dietz, A. and D.W. Thayer. eds.), 225-291.

[21]. Lechevalier. M.P., Prauser.H, Labeda.D.P, Ruan.J.S and Lechevalier. H.A. (2010). Two new genera of nocardioform actinomycetes: Amyco/ata gen. nov. and Amyco/atopsis gen. nov. Int. J. Syst. Bacteriol. 36:29-37.

[22]. Mincer TJ, Jensen PR, Kauffman CA, Fenical W, (2009), Widespread and persistent populations of a major new marine actinomycete taxon in ocean sediments. Appl Environ Microbiol , 68: 5005-5011.

[23]. Nathan A. Magarvey, Keller.J.M, Bernan.V, Dworkin.M, and Sherman.D.H, (2008), Isolation and Characterization of Novel Marine-Derived Actinomycete Taxa Rich in Bioactive Metabolites Appl Environ Microbiol; 70(12): 7520-7529.

[24]. Pandey A, Shukla A, Majumdar SK (2009). Utilization of carbon and nitrogen sources by Streptomyces kanamyceticus M27 for the production of an anti bacterial antibiotic. Afr. J. Biotechol. 4: 909-910.

[25]. Satheeja Santhi.S, Jose.A, and Solomon.J, R.D (2010), Isolation and Characterization of antagonistic actinomycetes from Mangrove sediments, International Journal of Current Research, 3: 020-023. 